\title{
Species differences in restraint-induced gastric ulcers
}

\author{
GARY B. GLAVIN \\ Brock University, St. Catharines, Ontario L2S 3A1, Canada \\ and \\ GEORGE P. VINCENT \\ Veterans Administration Medical Center, Perry Point, Maryland 21902
}

Rats, hamsters, gerbils, guinea pigs, and mice were starved for $12 \mathrm{~h}$ and then subjected to $3 \mathrm{~h}$ of cold restraint $\left(4^{\circ} \mathrm{C}-6^{\circ} \mathrm{C}\right)$ in either the prone or the supine position. Significant differences occurred between restraint positions and between species. All species exhibited glandular stomach ulceration in response to both forms of stress.

Immobilization or restraint has been extensively employed as an ulcerogenic technique (Ader, 1971; Glavin \& Mikhail, 1976). Two recent modifications of the original restraint procedures have enhanced their efficacy and reliability. The first change involved the use of a cold $\left(4^{\circ} \mathrm{C}-6^{\circ} \mathrm{C}\right)$ environment in which to restrain the animals. Restraint in such an environment produces more frequent and more severe gastric lesions than does restraint at room temperature (Senay \& Levine, 1967). The second modification involved restraining animals in the supine as opposed to the prone position (Vincent, Glavin, Rutkowski, \& Paré, 1977). Restraining animals under these conditions increases the severity of the ulcers produced, obviates the need for long periods of starvation prior to restraint, and increases the uniformity and reliability of the ulcers produced.

Supine cold restraint is a relatively new ulcerogenic procedure that has been used primarily with rats. Lee and Bianchi (1971) suggested that one important criterion for evaluating ulcerogenic techniques is the extent to which the method is capable of producing stomach ulcers in a variety of animal species. The present study was designed to assess the ulcerogenic effects of supine cold restraint in five species of rodents.

\section{METHOD}

\section{Subjects}

Thirty male Wistar rats $(180-200 \mathrm{~g}$ at the start of the study), 30 male LHC/LoK hamsters (85-105 $\mathrm{g}$ at the start of the study), 30 male gerbils $(50-70 \mathrm{~g}$ at the start of the study), 30 male HOR $F_{1}$ guinea pigs $(240-300 \mathrm{~g}$ at the start of the study), and 30 male HPB Swiss Webster albino mice (20-30 g at the start of the study) were used as subjects. All animals within a species were randomly assigned to treatment conditions.

\section{Apparatus}

Animals were restrained by specially constructed harnesses consisting of a wooden board $(22 \times 13 \times 1.5 \mathrm{~cm})$. A wide $(10-\mathrm{cm})$ leather band was drawn over the animal's thorax and secured beneath the board. Each limb was drawn out at a 45-deg angle from the body and secured with leather thongs $(.5 \mathrm{~cm}$ in width). Animals were placed in a ventilated refrigerator maintained at a temperature between $4^{\circ} \mathrm{C}$ and $6^{\circ} \mathrm{C}$.

\section{Procedure}

All animals within each species were randomly assigned to one of three conditions: food deprivation for $12 \mathrm{~h}$ followed by $3 \mathrm{~h}$ of supine cold restraint, $12 \mathrm{~h}$ of food deprivation followed by $3 \mathrm{~h}$ of prone cold restraint, or $12 \mathrm{~h}$ of food deprivation without restraint. There were 10 animals of each species in each condition. Following the restraint procedure (or the fooddeprivation period in the case of the control groups), animals were killed with chloroform, and their stomachs were excised, cleaned, and examined for ulcers. The number of lesions was counted, and the size of the lesions was determined by measuring the length and width and expressing this measure as cumulative length in millimeters.

\section{RESULTS}

Table 1 illustrates that all restrained animals developed glandular ulcers. A very few, minute lesions were observed in four animals starved but not restrained (two hamsters and two gerbils). Analysis of variance indicated that supine restraint produced significantly more frequent and significantly more severe glandular ulceration than did restraint in the prone position $(p<.001)$. Rats, mice, and guinea pigs ulcerated significantly more than hamsters and gerbils $(p<.01)$. Because of the difference in size of the stomachs of the five species, differences in the extent of glandular ulceration were evaluated by comparing the percentage area of the glandular stomach that was ulcerated; this is also shown in Table 1. Again, rats and mice ulcerated significantly more than the other species $(p<.01)$. Most importantly, however, was the observation that all five species displayed a reliably high incidence of readily discernible glandular ulcers in response to supine cold restraint. 
Table 1

Summary of Glandular Stomach Pathology for Supine and Prone Restraint for Each Species

\begin{tabular}{|c|c|c|c|c|c|}
\hline & $\mathrm{N}$ & $\begin{array}{c}\text { Number } \\
\text { with } \\
\text { Ulcers }\end{array}$ & $\begin{array}{c}\text { Mean } \\
\text { Number } \\
\text { of Ulcers }\end{array}$ & Length* & Percent** \\
\hline & \multicolumn{5}{|c|}{ Rat } \\
\hline Supine & 10 & 10 & 10.0 & 9.9 & 4.31 \\
\hline Prone & 10 & 8 & 5.6 & 5.3 & 3.69 \\
\hline \multirow[t]{2}{*}{ Control } & 10 & 0 & .0 & .0 & .00 \\
\hline & \multicolumn{5}{|c|}{ Guinea Pig } \\
\hline Supine & 10 & 10 & 8.4 & 6.8 & .81 \\
\hline Prone & 10 & 8 & 4.6 & 2.4 & .34 \\
\hline \multirow[t]{2}{*}{ Control } & 10 & 0 & .0 & .0 & .00 \\
\hline & \multicolumn{5}{|c|}{ Mouse } \\
\hline Supine & 10 & 10 & 9.7 & 4.8 & 6.64 \\
\hline Prone & 10 & 7 & 4.1 & 2.5 & 4.18 \\
\hline \multirow[t]{2}{*}{ Control } & 10 & 0 & .0 & .0 & .00 \\
\hline & \multicolumn{5}{|c|}{ Hamster } \\
\hline Supine & 10 & 8 & 6.8 & 2.4 & .24 \\
\hline Prone & 10 & 8 & 4.3 & 1.6 & .199 \\
\hline \multirow[t]{2}{*}{ Control } & 10 & 2 & .2 & .1 & .003 \\
\hline & \multicolumn{5}{|c|}{ Gerbil } \\
\hline Supine & 9 & 6 & 3.0 & 7.5 & 1.74 \\
\hline Prone & 10 & 8 & 3.1 & 7.5 & 1.30 \\
\hline Control & 7 & 2 & .2 & .7 & 1.09 \\
\hline
\end{tabular}

*Mean cumulative length in millimeters.

**Mean percent of stomach ulcerated.

\section{DISCUSSION}

In reviewing the literature on restraint-induced ulceration, Brodie (1968) noted, "About the most that can be asked is that the method used produce a consistently high incidence of readily discernible ulcers in the area of the gastrointestinal tract of interest" (p. 125). Lee and Bianchi (1971) suggested that one of the criteria of a useful ulcer model is the extent to which it produces lesions in a variety of species. The present results suggest that supine cold restraint is an acceptable ulcerogenic procedure in light of either Brodie's or Lee and Bianchi's criteria. It appears that supine cold restraint-induced gastric ulcers are not unique to the rat but can be generalized with confidence to other species. As such, this procedure represents a useful tool in the investigation of the etiology and prevention of stress ulceration.

\section{REFERENCES}

Ade R, R. Experimentally induced gastric lesions. In H. Weiner (Ed.), Advances in psychosomatic medicine: Duodenal ulcer. Basel: Karger, 1971.

Brodie, D. A. Experimental peptic ulcer. Gastroenterology, 1968, 55, 125-134.

Glavin, G. B., \& Mikhail, A. A. The role of gastric acid in restraint-induced ulceration in the rat. Physiology \& Behavior, 1976, 17, 777-780.

LEE, Y. H., \& BIANCHI, R. C. Use of experimental peptic ulcer models for drug screening. In C. J. Pfeiffer (Ed.), Peptic ulcer. Philadelphia: Lippincott, 1971.

Senay, E. C., \& Levine, R. J. Synergism between cold and restraint for rapid production of stress ulcers in rats. Proceedings of the Society for Experimental Biology and Medicine, 1967, 124, 1221-1223.

Vincent, G. P., Glavin, G. B., Rutkowski, J. L., \& Paré, W. P. Body orientation, food deprivation and potentiation of restraint-induced gastric lesions. Gastroenterologie Clinique et Biologique, 1977, 1, 539-543.

(Received for publication August 14, 1979.) 